\title{
Pengaruh Kualitas Pelayanan dan Kepuasan Terhadap Loyalitas Pelanggan pada PT. Pos Cabang Singaraja
}

\author{
Ketut Valien Wira Atmaja ${ }^{1}$, I Nyoman Sujana ${ }^{2}$, Kadek Rai Suwena $^{3}$ \\ Jurusan Pendidikan Ekonomi \\ Universitas Pendidikan Ganesha \\ Singaraja, Indonesia
}

\begin{abstract}
e-mail: valienwira2804@gmail.com', sujanatbn@yahoo.com², kadek suwena@yahoo.co.id ${ }^{3}$
\end{abstract}

\begin{abstract}
Abstrak
Penelitian ini bertujuan untuk mengetahui pengaruh langsung kualitas pelayanan dan kepuasan terhadap loyalitas pelanggan Kantor Pos secara parsial, pengaruh langsung kualitas pelayanan terhadap kepuasan, dan pengaruh tidak langsung kualitas pelayanan terhadap loyalitas pelanggan Kantor Pos melalui kepuasan. Penelitian ini merupakan jenis penelitian kuantitatif. Metode penelitian pengumpulan data ini menggunakan kuesioner berupa angket yang disebar kepada 100 responden. Metode analisis yang digunakan dalam penelitian ini adalah analisis jalur. Menggunakan bantuan SPSS 24.0 for Windows. Dari hasil peneliatan yang diperoleh ada pengaruh langsung kualitas pelayanan terhadap loyalitas pelanggan sebesar 0,064 , ada pengaruh langsung kepuasan terhadap loyalitas pelanggan sebesar 0,787 , ada pengaruh langsung kualitas pelayanan terhadap kepuasan sebesar 0,109 , ada pengaruh tidak langsung kualitas pelayanan terhadap loyalitas pelanggan melalui kepuasan sebesar 0,086.
\end{abstract}

Kata kunci: kualitas pelayanan, kepuasan terhadap loyalitas

\begin{abstract}
This study aims to determine the influence of direct service quality and satisfaction with customer loyalty in partial of Post Office, the direct service quality to satisfaction, and the indirect influence of service quality to customer loyalty of Post Office through satisfaction. This research is a quantitative research. The research method of collecting this data using questionnaires in the form of questionnaires distributed to 100 respondents. This research used method of path analysis with used SPSS 24.0 for Windows. From the result of this research there is direct influence of service quality to customer loyalty equal to 0,064 , there is direct influence of satisfaction to customer loyalty equal to 0,787 , there is direct influence of service quality to satisfaction equal to 0,109 , there is indirect quality of service to customer loyalty through satisfaction equal to 0,086 .
\end{abstract}

Keywords : service quality, satisfaction with loyalty

\section{PENDAHULUAN}

Persaingan bisnis jasa yang semakin ketat di Indonesia dewasa ini memberikan pengaruh baik secara langsung maupun tidak langsung terhadap perusahaan. Persaingan yang ketat ini menyebabkan perusahaan di Indonesia berlomba mengembangkan perusahaanya untuk mendapkan perhatian konsumen. Sebagai contoh di Bali, banyak bermunculan bisnis jasa seperti biro perjalanan wisata, penginapan dan pengiriman barang (ekspedisi). Menurut Solomon (2003:7) Jasa adalah produk yang tidak 
dapat dilihat yang kita beli dan gunakan tetapi tidak pernah memiliki.

Jasa ekspedisi adalah salah satu jasa yang bergerak dibidang pengiriman barang. Secara umum pelayanan jasa pengiriman barang adalah segala upaya yang diselenggarakan atau dilaksanakan secara sendiri atau secara bersama-sama dalam suatu organisasi untuk memberikan pelayanan secara efektif dan efisien. Di Indonesia jasa pengiriman/jasa ekspedisi sangatlah penting karena luas daerah Indonesia dan terdiri dari banyak pulau. Maka jasa ekspedisi/pengiriman barang sangat efektif dan efesien waktu. Di kota Singaraja sangat berkembang jasa ekpedisi seperti JNE, JNT, TIKI, dan Kantor Pos sehingga menuntut pihak pengusaha menyusun kebijakan untuk menghadapi persaingan yang ada. Salah satu usaha untuk menghadapi persaingan tersebut adalah perusahaan memberikan pelayanan yang terbaik. Selain untuk mendapatkan laba perusahaan juga menginginkan agar pelanggan tetap loyal terhadap perusahaan.

Sopiah (2013:105) "Loyalitas lebih ditunjukan pada suatu perilaku, yang ditunjukkan dengan pembelian rutin. Dan didasarkan pada unit pengambilan keputusan". Griffin (dalam Sopiah 2013). Loyalitas adalah mengacu pada wujud perilaku dari unit-unit pengambilan keputusan untuk melakukan pembelian secara terus-menerus terhadap barang atau jasa dari suatu perusahaan yang dipilih. Oliver (dalam Vanessa 2007) Loyalitas pelanggan adalah komitmen untuk bertahan secara mendalam untuk melakukan pembelian ulang atau berlangganan kembali produk atau jasa terpilih secara konsisten dimasa yang akan datang, meskipun pengaruh situasi dan usaha- usaha pemasaran mempunyai potensi untuk menyebabkan perubahan perilaku. Apabila pelanggan puas terhadap jasa atau barang yang diberikan, maka akan menimbulkan kesetiaan pelanggan sehingga membuat pelanggan menjadi loyal. Untuk meningkatkan loyalitas, perusahaan harus meningkatkan kepuasaan setiap pelanggan dan mempertahankan tingkat kepuasaan tersebut dalam jangka panjang.
Kepuasaan konsumen merupakan suatu hal yang sangat penting. Untuk bertahan di dunia bisnis terutama dibidang jasa, kelangsungan hidup sebuah perusahaan sangat tergantung pada kepuasan para pelanggannya. Upayaupaya yang akan dilakukan oleh perusahaan untuk memuaskan kebutuhan konsumen dengan berbagai strategi dan berbagai cara dengan harapan agar konsumen merasa puas dengan kualitas pelayanan yang diberikan perusahaan.

Kualitas pelayanan adalah salah satu faktor yang akan mempengaruhi loyalitas pelanggan yaitu ketika seseorang mendapatkan pengalaman pada perusahaan yang dapat membentuk perilaku Zikmund (dalam Vanessa, 2007:72). Dimana dibuktikan kualitas pelayanan mempengaruhi kepuasan pelanggan sehingga menjadi suatu respon kepada konsumen atas apa yang sudah diterima. Masalah pelayanan sebenarnya bukanlah hal yang rumit atau sulit, tetapi apabila hal ini tidak diperhatikan maka dapat menimbulkan hal-hal yang rawan karena sifatnya yang sangat sensitif.

PT Kantor Pos adalah salah satu perusahaan yang bergerak dibidang pelayanan yaitu jasa pengiriman barang (ekspedisi). Kantor Pos merupakan perusahaan jasa pengiriman (ekspedisi) tertua yang masih bertahan. Kantor pos dikatakan tertua terbukti kator pos sudah berdiri pertama kali di Batavia (sekarang Jakarta) pada tanggal 26 agustus 1746 . Usia perusahan tidak menjamin perusahan kantor pos tidak mengalami masalah ataupun kesalahan dalam manajemen perusahaan, masih,ada permasalaah kualitas pelayanan yang masih membuat pelanggan kurang puas dalam kualitas pelayanan jasa kantor pos. Dari penelitian awalnya yang dilakukan, diketahui ada beberapa komplain berkaitan dengan pelayanan diantaranya.

Pada bulan Juli 2016 terjadi 7 masalah komplain karena keterlambatan. Bulan Agustus 2016 terjadi 7 komplain karena masalah keterlambatan pengiriman. September 2016 terjadi 4 komplain karena masalah keterlambatan pengiriman. Oktober 2016 terjadi 10 komplain karena masalah keterlambatan pengiriman 
barang dan 1 komplain masalah karena kerusahaan barang. November 2016 terjadi 8 komplain karena masalah keterlambatan pengiriman barang. Desember 2016 terjadi 12 komplain karena masalah keterlambatan pengiriman barang.

Adanya komplain dari pelanggan tersebut sedikit tidaknya akan berdampak kepada penilaian pelanggan terhadap kinerja PT Kantor Pos akan menurun atau tidak baik. Ini akan berdampak pada kepuasan pelanggan. Berdasarkan permasalahan tersebut maka dipandang perlu untuk melakukan penelitian yang dituangkan dalam judul "Pengaruh Kualitas Pelayanan dan Kepuasan terhadap Loyalitas Pelanggan Kantor Pos Cabang Pusat Singaraja".

Christopher

mendefinisikan "kualitas layanan sebagai sesuatu yang secara konsisten memenuhi atau melampaui harapan pelanggan". Sentot (2010:178) menyatakan "bahwa kualitas layanan adalah penentu kepercayaan pelanggan terhadap perushaan dan produk-produknya". Selanjutnya Tjiptono (dalam Sopiah, 2013) menjelaskan bahwa apabila jasa diterima atau disaranan sesuai dengan yang diharapkan, kualitas jasa dipersepsikan baik dan memuaskan. Jika jasa yang diterima melampaui harapan pelanggan, kualitas jasa dipersepsikan sebagai kualitas yang ideal. Sebaliknya, apabila jasa yang diterima lebih rendah daripada yang diharapkan, kualitas jasa dipersepsikan buruk. Garvin (dalam Sopiah, 2013) menyatakan lima macam perspektif kualitas yang berkembang. Kelima macam perspektif inilah yang bisa menjelaskan mengapa kualitas bisa diartikan beraneka ragam oleh orang yang berbeda dalam situasi yang berlainan. Adapun kelima macam perspektif kualitas tersebut adalah Pendekatan transcendental (transcendental approach) Dalam pendekatan ini kualitas dipandang sebagai keunggulan bawaan (innate excellence), di mana kualitas dapat dirasakan atau diketahui, tetapi sulit didefinisikan dan dioperasionalisasikan. Pendekatan berbasis produk (productbased approach) Pendekatan ini menganggap bahwa kualitas merupakan karakteristik atau atribut yang dapat dikuantitatifkan dan dapat diukur. Pendekatan berbasis pengguna (userbased approach) Pendekatan ini didasarkan pada pemikiran bahwa kualitas tergantung pada orang yang memandangnya sehingga produk yang paling memuaskan prefensi seseorang (misalnya, kualitas yang dirasakan [perceived quality]) merupakan produk yang berkualitas paling tinggi. Pendekatan berbasis manufaktur (manufacturingbased approach) Perspektif ini bersifat berdasarkan pasokan (supply-based) dan secara khusus memperhatikan praktikpraktik perekayasaan dan kemanufakturan, serta mendefinisikan kualitas sebagai kesesuaian atau kesamaan dengan persyaratan (conformance to requirements). Penentu kualitas dalam pendekatan ini adalah standar-standar yang ditetapkan perusahaan, bukan oleh konsumen pengguna. Pendekatan berbasis nilai (value-based approach) Kualitas dalam perspektif ini bersifat relatif sehingga produk yang paling bernilai adalah barang atau jasa yang paling tepat untuk dibeli (best-buy).

Dari beberapa definisi para ahli, dapat disimpulkan bahwa, kualitas jasa sangat berperan penting dalam kemajuan suatu perusahaan apabila konsumen merasa layanan yang diberikan memenuhi atau melebihi harapan maka perusahan akan dipersepsikan baik oleh konsumen. Sebaliknya, apabila jasa yang diterima lebih rendah daripada yang diharapkan, kualitas jasa dipersepsikan buruk. Dengan demikian, baik tidaknya kualitas pelayanan tergantung pada kemampuan penyedia jasa untuk memenuhi harapan pelanggan secara konsisten. Kualitas pelayanan ini menjadi penting karena akan berdampak langsung pada citra perusahaan. Kualitas pelayanan yang akan menjadi keuntungan bagi perusahaan. Jika perusahaan sudah mendapat nilai positif di mata konsumen, maka konsumen tersebut akan memberikan feedback yang baik, serta bukan tidak mungkin akan menjadi pelanggan tetap atau repeat buyer. Maka dari itu, sangat penting untuk 
mempertimbangkan aspek kepuasan pelanggan terkait kualitas pelayanan yang diberikan.

Christopher (2010) menyatakan dimensi generik yang digunakan oleh pelanggan untuk mengevaluasi kualitas pelayanan yaitu berwujud (tangible), yaitu penampilan fasilitas fisik, peralatan, personil, dan materi komunikasi. Kehandalan (reability), yaitu kemampuan untuk melakukan pelayananyang dijanjikan, dapat diandalkan, dan akurat.

Responsiveness, yaitu Kesediaan untuk membantu pelanggan dan menyediakan prompt pelayanan. Assurance, kredibilitas (kepercayaan, kejujuran penyedia pelayanan), keamanan (kebebasan dari bahaya, risiko, atau keraguan), kompetensi (memiliki keterampilan dan pengetahuan yang diperlukan untuk melaksanakan pelayanan), sopan-santun (kesopanan, rasa hormat, pertimbangan, dan keramahan personel layanan), empati. Akses (mudah didekati dan mudah untuk dikontak), komunikasi (mendengarkan pelanggan dan mejaga agar mereka terinformasikan dalam bahasa yang bisa mengerti), memahami pelanggan (membuat upaya untuk mengenali pelanggan dan kebutuhan mereka)

Irawan (2002:2) menyatakan bahwa "pelanggan yang puas adalah pelanggan yang akan berbagi kepuasan dengan produsen atau pelayan jasa. Bahkan, pelanggan yang puas, akan berbagi rasa dan pengalaman dengan pelanggan lain". Selanjutnya McKechnie (dalam Sopiah 2013) mengemukakan bahwa kepuasan pelanggan pada dasarnya adalah fungsi dari harapan dan persepsi terhadap kinerja suatu produk setelah pelanggan mendapatkan atau menggunakan layanan. Setelah mengonsumsi produk, konsumen akan merasakan kepuasan atau kekecewaan. Kepuasan akan mendorong konsumen untuk membeli ulang produk. Sebaliknya, jika kecewa, konsumen tidak akan membeli produk yang sama lagi dikemudian hari. Kepuasan konsumen merupakan evaluasi purnabeli di mana alternatif yang dipilih sekurang-kurangnya sama atau melampaui harapan konsumen.
Kekecewaan timbul apabila kinerja yang aktual tidak memenuhi harpan konsumen.

Dari beberapa definisi para ahli, dapat disimpulkan bahwa, kepuasan dapat diartikan sebagai adanya kesamaan antara kinerja produk dan pelayanan yang diharapkan konsumen. Dalam era kompetisi bisnis yang ketat seperti sekarang, kepuasan konsumen merupakan hal yang utama. Konsumen diibaratkan sebagai raja yang harus dilayani, meskipun hal ini bukan berarti menyerahkan segala-galanya kepada konsumen. Usaha memuaskan kebutuhan konsumen harus dilakukan secara menguntungkan atau dengan situasi sama menang, yaitu keadaan di mana kedua belah pihak merasa puas dan tidak ada yang dirugikan.

Sentot (2010) menyatakan ada beberapa faktor yang mempengaruhi kepuasan pelanggan yaitu Fitur produk dan jasa, kepuasan pelanggan terhadap pelanggan produk atau jasa secara signifikan dipengaruhi oleh evaluasi pelanggan terhadap fitur produk atau jasa. Peneliti juga menunjukan bahwa pelanggan jasa akan membuat trade-off antara fitur jasa yang berbeda (misalnya, tingkat harga dengan kualitas, atau dengan keramahan karyawan), tergantung pada tipe jasa yang dievaluasi dan tingkat kekritisan jasa, mosi pelanggan, emosi juga dapat mempengaruhi persepsi pelanggan terhadap produk atau jasa. Emosi ini dapat stabil seperti keadaan pikiran atau perasaan atau kepuasan hidup. Pikiran atau perasaan pelanggan. (good mood atau bad mood) dapat mempengaruhi respon pelanggan terhadap jasa. Emosi spesifik juga dapat disebabkan oleh pengalaman konsumsi, yang mempengaruhi kepuasan pelanggan terhadap jasa. Atribusi untuk keberhasilan atau kegagalan jasa, atribusi penyebab yang dirasakan dari peristiwa mempengaruhi persepsi dari kepuasan. Ketika pelanggan dikejutkan dengan hasil (jasa lebih baik atau lebih buruk dari yang diharapkan), pelanggan cenderung untuk melihat alasan, dan penilaian mereka terhadap alasan dapat mempengaruhi kepusan, persepsi terhadap kewajaran dan keadilan (equity and fairness) 
Kepuasan pelanggan juga dipengaruhi oleh persepsi pelanggan terhadap kewajaran dan keadilan. Pelanggan bertanya pada diri mereka: Apakah saya diperlakukan secara baik dibandingkan dengan pelanggan lain? Apakah pelanggan lain lain mendapatkan pelayanan yang lebih baik, harga yang lebih baik, atau kualitas jasa yang lebih baik? Apakah saya membayar dengan harga yang wajar untuk jasa yang saya beli?

Pelanggan lain, keluarga, dan rekan kerja Kepuasan pelanggan juga dipengaruhi oleh orang lain. Misalnya, kepuasan terhadap perjalanan liburan keluarga adalah fenomena yang dinamis, dipengaruhi oleh reaksi dan ekspresi oleh anggota keluarga selama liburan. Kemudian, apakah ekspresi kepuasan atau ketidakpuasan anggota keluarga terhadap perjalanan dipengaruhi oleh cerita yang diceritakan kembali di antara keluarga dan memori mengenai suatu persistiwa.

Memiliki pelanggan yang loyal adalah salah satu tujuan akhir dari perusahaan karena loyalitas pelanggan dapat menjamin kelanggengan hidup perusahaan dalam jangka panjang. Hal ini sesuai dengan pendapat para ahli. Nugroho (2003:129) menyatakan "loyalitas adalah seorang konsumen yang sudah sangat sering melakukan pembelian terhadap suatu merek produk. Tidak ada lagi merek yang dipertimbangkan untuk dibeli selain merek produk yang sering dibelinya". Selanjutnya Zulkarnain (2012:136) menyatakan "loyalitas pelanggan adalah suatu perilaku pembelian yang positif ditunjukan pelanggan terhadap perusahaa, merek, toko, pemasok yang dilakukan secara teratur, konsisten dan berkesinambungan serta berulang-ulang dalam kurun waktu yang lama".

Dari beberapa definisi para ahli, dapat disimpulkan bahwa loyalitas adalah sebuah kesetiaan konsumen terhadap perusahan/merek ditunjukan dengan cara konsumen melakukan pembelian ulang secara teratur, bahkan perusahaan akan merekomendasikan perusahaaan kepada orang lain yang meminta saran.
Hakikatnya loyalitas pelanggan diibaratkan sebagai perkawinan antara perusahaan dan publik. Jalinan relasi ini akan berlangsung berkesinambungan karna didasari kepercayaan pelanggan terhadap perusahaan.

Zikmund (dalam Vanesa 2007) menyatakan ada beberapa faktor yang mempengaruhi loyalitas pelanggan yaitu kepuasan, merupakan perbandingan antara harapan sebelum melakukan pembelian dengan kinerja yang dirasakan, Ikatan emosi, dimana konsumen dapat dipengaruhi oleh sebuah merek yang memiliki daya tarik tersendiri sehingga konsumen diindetifikasikan dalam sebuah merek, karena sebuah merek dapat mencerminkan karakteristik konsumen tersebut. Ikatan yang tercipta dari sebuah merek ialah ketika konsumen merasakan ikatan yang kuat dengan konsumen lain yang menggunakan produk atau jasa yang sama. Kepercayaan, merupakan komponen ketiga yang memiliki keterkaitan dengan ikatan emosi yaitu kemauan seseorang untuk mempercayakan perusahan atau sebuah merek untuk melakukan atau menjalankan sebuah fungsi. Kemudahan, yaitu jika konsumen akan merasa nyaman dengan sebuah merek ketika situasi mereka melakukan transaksi memberikan kemudahan. Dengan pengulangan yang sederhana kemudahan kita akan lebih mengenal merek, toko, perusahaan. Pengalaman terhadap perusahan, yaitu sebuah pengalaman seseorang pada perusahaan dapat membentuk perilaku. Ketika kita mendapatkan pelayanan yang baik dari perusahaan. Maka kita akan mengulangi perilaku kita pada perusahaan tersebut.

\section{METODE}

Penelitian ini termasuk penelitian Kuantitatif. Rancangan penelitian dalam penelitian ini adalah penelitian asosiatif kausalitas. Pendekatan asosiatif adalah pendekatan untuk mengetahui ada tidaknya hubungan antar variabel yang diteliti. Desain kausalitas digunakan untuk mengetahui apakah variabel-variabel yang diamati mempunyai hubungan sebab akibat tertentu yang diduga secara teoritis. 
Analisis yang digunakan dalam penelitian ini adalah analisis jalur (path analysis), yang merupakan suatu bentuk terapan dari analisis regresi berganda (multiple regression), di mana teknik tersebut akan menguji hipotesis yang menyatakan ada pengaruh antara variabel bebas terhadap variabel intervening dan variabel intervening terhadap variabel terikat serta pengaruh tidak langsung dari variabel bebas terhadap variabel terikat melalui variabel intervening.

Penelitian ini dilakukan di PT. Pos cabang Singaraja. Hal ini dilakukan untuk menyebarkan kuesioner kepada pelanggan PT. Pos cabang Singaraja. Adapun subjek dalam penelitian ini adalah pelanggan PT. Pos cabang Singaraja. Objek dalam penelitian ini adalah pengaruh kualitas pelayanan dan

$\mathrm{n}=\frac{N}{1+N e^{2}}$

keterangan:

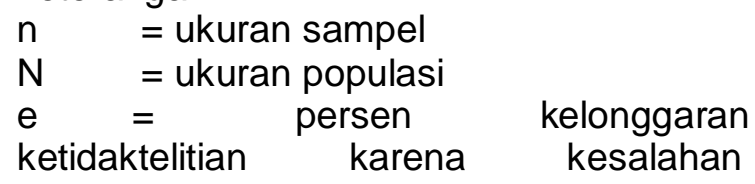

ditolerir atau diinginkan misalnya $10 \%$. Maka dapat diperoleh hasil sebagai berikut.

$$
\begin{aligned}
& n=\frac{23199}{1+23199(0,10)^{2}} \\
& n=\frac{23199}{1+23199(0,01)} \\
& n=\frac{23199}{1+231,99} \\
& n=\frac{23199}{232,99}
\end{aligned}
$$

$\mathrm{n}=99,5$ (dibulatkan menjadi 100 responden)

Jadi jumlah keseluruhan pelanggan PT. Pos cabang Singaraja yang diambil sebagai sampel penelitian ini adalah 100 responden. Metode pengumpulan data yang digunakan dalam penelitian ini adalah kuisioner .

Sebelum kuesioner disebarkan kepada responden, kuesioner akan diuji terlebih dahulu. Adapun pengujian yang dipergunakan adalah sebagai berikut. Uji Validitas, uji Validitas instrumen menggunakan teknik analisis korelasi
Product Moment Person, dengan rumus sebagai berikut.

$r x y=\frac{N \Sigma X Y-(\bar{\Sigma} X)(\Sigma Y)}{\sqrt{\{N \Sigma X 2-(\Sigma X) 2\}(N \Sigma Y 2-(\Sigma Y) 2\}}}$

Keterangan:

$r_{x y} \quad=$ koefisien korelasi yang dicari

$\mathrm{N} \quad=$ banyaknya responden

$\mathrm{X}=$ skor item instrument yang akan digunakan

$\mathrm{Y}=$ skor semua item instrument dalam variabel tersebut.

Pengujian validitas menggunakan

korelasi Product-Moment Pearson dibantu dengan program Statistic Product and Service Solution (SPSS) for Windows.

Uji Reliabilitas, uji reliabilitas untuk instrumen penelitian ini menggunakan rumus Alpha.Adapun rumus Alpha sebagai berikut.

$r_{11}=\left[\frac{K}{(K-1}\right]\left[\frac{\sum \sigma b^{2}}{\sigma t^{2}}\right]$

Keterangan:

$r_{11}=$ reliabilitas instrumen

$\mathrm{k}=$ banyak butir pertanyaan atau banyak soal

$\sum \sigma b^{2}=$ jumlah varians butir

$\sigma t^{2}=$ varians total

Pengolahan data dalam penelitian ini

Product and Service Solution (SPSS) for windows.

Adapun langkah-langkah dalam analisis jalur (path analysis) menurut solimun (2002), sebagai berikut, langkah pertama ialah merancang model berdasarkan konsep dan teori. Model tersebut dapat dinyatakan dalam bentuk persamaan, sehingga membentuk sistem persamaan. Langkah kedua ialah melakukan pemeriksaan terhadap asumsi yang melandasi analisis jalur, diantaranya adalah sebagai berikut. Dalam model analis jalur, hubungan antar variabel

adalah linier. Uji linieritas menggunakan curve fit dan menerapkan prinsip parsimony. Prinsip parsimony ialah apabila seluruh model signifikan atau non signifikan, maka model tersebut dapat dikatakan berbentuk linier. Hanya model rekrusif dapat dipertimbangkan, yaitu hanya sistem aliran kausal ke satu arah, sedangkan pada model yang mengandunghubungan kausal resiprokal 
tidak dapat dilakukan analisis jalur. Pengamatan diukur tanpa kesalahan (instrumen pengukuran valid dan reliabel). Model yang dianalisis diidentifikasi dengan benar berdasarkan teori-teori dan konsepkonsep relevan. Langkah ketiga adalah pemeriksaan validitas suatu kesalahan model. Terdapat indikator validitas model di dalam analisis jalur, yaitu koefisien determinasi total. Langkah keempat dalam analisis jalur adalah pendugaan parameter atau perhitungan koefisien path. Koefisien jalur adalah koefisien regresi yang distandarkan yang digunakan untuk menjelaskan besarnya pengaruh variabel bebas terhadap variabel lain yang diberlakukan sebagai variabel terikat. Koefisien path ditunjukan oleh output yang dikenal dengan nilai Beta. Perhitungan koefisien pada gambar diagram jalur pada uraian sebelumnya dijelaskan sebagai berikut. Perhitungan koefisien path untuk anak panah satu arah digunakan perhitungan regresi variable dibakukan, secara parsial pada masing-masing persamaan. Metode yang digunakan adalah OLS (Ordinary Least Square), yaitu metode kuadrat terkecil biasa. Hal ini dapat dilakukan mengingat modelnya regrusif. Dari perhitungan ini diperoleh koefisien path pengaruh langsung. Pengaruh tidak langsung dan pengaruh total dapat dihitung dengan cara, pengaruh langsung $X_{1}$ ke $Y$ melalui $X_{2}=$ $P_{x 2 x} X 1 \times \rho_{y x 1}$, untuk perhitungan pengaruh total dapat dihitung dengan cara nilai koefisien jalur $\mathrm{X}_{1}$ terhadap $\mathrm{Y}$ ditambah dengan nilai koefisien jalur $\mathrm{X}_{2}$ terhadap $\mathrm{Y}$. Langkah kelima adalah pemeriksaan validitas model. Sahih tidaknya suatu hasil analisis bergantung pada terpenuhi atau tidaknya asumsi yang melandasinya. Pemeriksaan validitas model dalam penelitian ini menggunakan koefisien determinal total. Koefisien determinal total merupakan keragaman data yang dapat dijelaskan oleh model. Langkah keenam adalah langkah terakhir pada analisis jalur yaitu melakukan interprestasi hasil analisis. Pertama dengan memperhatikan hasil validitas model. Dan kedua adalah menghitung pengaruh total dari setiap variabel yang mempunyai pengaruh kausal ke variabel terikat. Bilamana analisis jalur telah dilaksanakan (berdasarkan sample), maka dapat dimanfaatkan untuk penjelasan terhadap fenomena yang dipelajari atau permasalahan yang diteliti.

\section{HASIL DAN PEMBAHASAN Hasil}

Pengaruh langsung antara kualitas pelayanan dengan loyalitas pelanggan, berdasarkan hasil analisis data menunjukkan bahwa pengaruh langsung antara kualitas pelayanan dengan loyalitas pelanggan PT Kantor Pos Pusat Cabang Singaraja dapat diketahui dengan menggunakan uji t. Perhitungan uji $t$ menggunakan bantuan program SPSS 24.0 for Windows dan pengujian hipotesis dilakukan pada taraf signifikansi $5 \%$. Hasil uji $\mathrm{t}$ dapat dilihat pada tabel 1 .

Tabel 1. Hasil Uji t Untuk Pengaruh Langsung Antara Kualitas Pelayanan Dengan Loyalitas Pelanggan

\begin{tabular}{|c|c|c|c|c|c|c|}
\hline \multirow{2}{*}{\multicolumn{2}{|c|}{ Model }} & \multicolumn{2}{|c|}{$\begin{array}{c}\text { Unstandardized } \\
\text { Coefficients }\end{array}$} & \multirow{2}{*}{$\begin{array}{c}\text { Standardized } \\
\text { Coefficients } \\
\text { Beta }\end{array}$} & \multirow[t]{2}{*}{$\mathrm{t}$} & \multirow[t]{2}{*}{ Sig. } \\
\hline & & $B$ & Std. Error & & & \\
\hline 1 & $\begin{array}{l}\text { (Constant) } \\
\text { Kualitas }\end{array}$ & $\begin{array}{c}19,578 \\
0,150\end{array}$ & $\begin{array}{l}3,150 \\
0,026\end{array}$ & 0,502 & $\begin{array}{l}6,216 \\
5,745\end{array}$ & $\begin{array}{l}0,000 \\
0,000\end{array}$ \\
\hline
\end{tabular}

pelayanan

a. Dependent Variable: Loyalitas pelanggan

Berdasarkan tabel 1 diperoleh nilai $\mathrm{t}$ hitung $=5,745$ dengan nilai $p$-value sebesar 0,000 . Nilai t hitung $=5,745$ lebih besar dari $t$ hitung $=1,984$ dan $p$-value sebesar 0,000 lebih kecil dari $\alpha=0,05$, maka keputusannya adalah $\mathrm{H}_{0}$ ditolak. Jadi, terdapat pengaruh yang signifikan antara kualitas pelayanan terhadap loyalitas pelanggan PT Kantor Pos Pusat Cabang
Singaraja. 
Pengaruh langsung antara kepuasan pelanggan dengan loyalitas pelanggan, berdasarkan hasil analisis data menunjukkan bahwa pengaruh langsung antara kepuasan pelanggan dengan loyalitas pelanggan PT Kantor Pos Pusat
Cabang Singaraja dapat diketahui dengan menggunakan uji t. Perhitungan uji $t$ menggunakan bantuan program SPSS 24.0 for Windows dan pengujian hipotesis dilakukan pada taraf signifikansi $5 \%$. Hasil uji t dapat dilihat pada tabel 2.

Tabel 2. Hasil Uji t Untuk Pengaruh Langsung Antara Kepuasan pelanggan Dengan Loyalitas Pelanggan

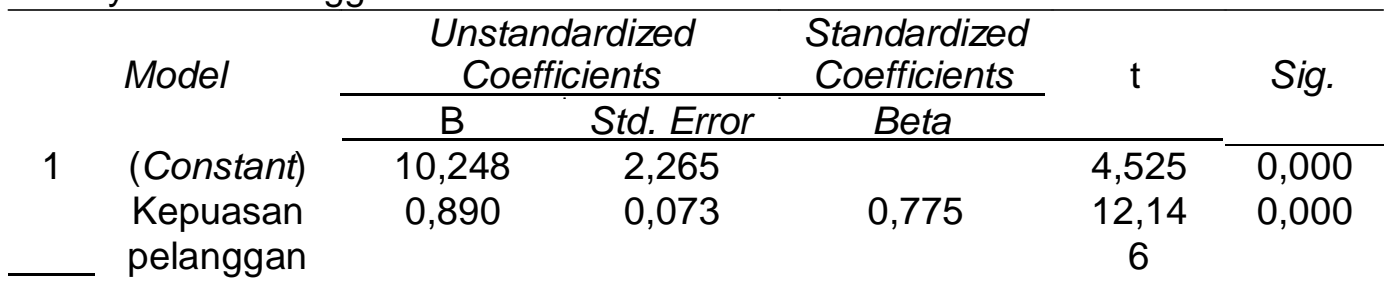

a. Dependent Variable: Loyalitas pelanggan

Berdasarkan hasil tabel 2 diperoleh nilai $t$ hitung $=12,146$ dengan nilai $p$-value sebesar 0,000 . Nilai t hitung $=12,146$ lebih besar dari t hitung $=1,984$ dan $p$-value sebesar 0,000 lebih kecil dari $\alpha=0,05$, maka keputusannya $\mathrm{H}_{0}$ ditolak. Jadi, terdapat pengaruh yang signifikan antara kepuasan pelanggan terhadap loyalitas pelanggan PT Kantor Pos Pusat Cabang Singaraja.

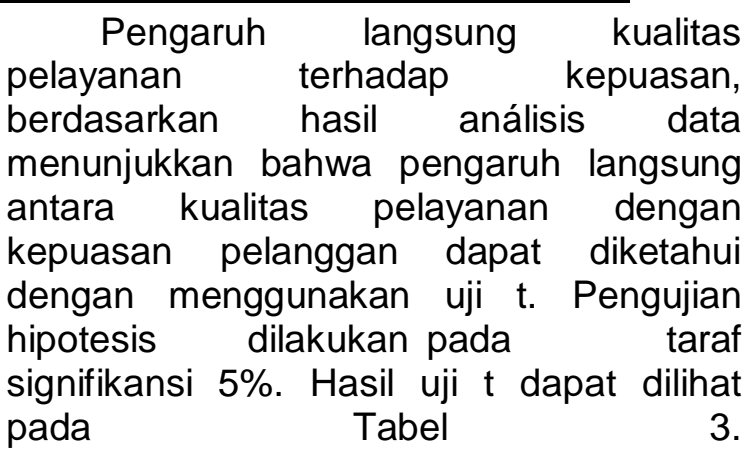

Tabel 3. Hasil Uji t Untuk Pengaruh Langsung Kualitas Pelayanan terhadap Kepuasan pelanggan

\begin{tabular}{|c|c|c|c|c|c|c|}
\hline & \multirow[t]{2}{*}{ Model } & \multicolumn{2}{|c|}{$\begin{array}{c}\text { Unstandardized } \\
\text { Coefficients }\end{array}$} & \multirow{2}{*}{$\begin{array}{c}\text { Standardized } \\
\text { Coefficients } \\
\text { Beta }\end{array}$} & \multirow[t]{2}{*}{ t } & \multirow[t]{2}{*}{ Sig. } \\
\hline & & $B$ & Std. Error & & & \\
\hline \multirow[t]{2}{*}{1} & (Constant) & 17,608 & 2,880 & & 6,114 & 0,000 \\
\hline & $\begin{array}{l}\text { Kualitas } \\
\text { pelayanan }\end{array}$ & 0,109 & 0,024 & 0,419 & 4,567 & 0,000 \\
\hline
\end{tabular}

Berdasarkan tabel 3 diperoleh nilai $\mathrm{t}$ hitung $=4,567$ dengan nilai $p$-value sebesar 0,000 . Nilai t hitung $=4,567$ lebih besar dari $\mathrm{t}$ tabel $=1,984$ dan $p$-value sebesar 0,000 lebih kecil dari $\alpha=0,05$, maka keputusannya $\mathrm{H}_{0}$ ditolak. Jadi, terdapat pengaruh yang signifikan antara kualitas pelayanan terhadap kepuasan pelanggan PT Kantor Pos Pusat Cabang Singaraja.
Pengaruh tidak langsung kualitas pelayanan terhadap loyalitas pelanggan melalui kepuasan, berdasarkan hasil analisis data menunjukkan bahwa pengaruh tidak langsung antara kualitas pelayanan dengan loyalitas pelanggan melalui kepuasan dapat diketahui dengan menggunakan uji t. Pengujian hipotesis dilakukan pada taraf signifikansi $5 \%$. Hasil uji $t$ dapat dilinat pada tabel 4 . 
Tabel 4. Hasil Uji t Untuk Pengaruh Tidak Langsung Antara Kualitas Pelayanan Dengan

\begin{tabular}{|c|c|c|c|c|c|c|}
\hline & \multirow[t]{2}{*}{ Model } & \multicolumn{2}{|c|}{$\begin{array}{c}\text { Unstandardized } \\
\text { Coefficients }\end{array}$} & \multirow{2}{*}{$\begin{array}{c}\text { Standardized } \\
\text { Coefficients } \\
\text { Beta }\end{array}$} & \multirow[t]{2}{*}{$\mathrm{t}$} & \multirow[t]{2}{*}{ Sig. } \\
\hline & & $B$ & Std. Error & & & \\
\hline \multirow[t]{3}{*}{1} & (Constant) & 5,729 & 2,585 & & 2,216 & 0,029 \\
\hline & $\begin{array}{l}\text { Kualitas } \\
\text { pelayanan }\end{array}$ & 0,064 & 0,020 & 0,215 & 3,199 & 0,002 \\
\hline & $\begin{array}{l}\text { Kepuasan } \\
\text { pelangaan }\end{array}$ & 0,787 & 0,077 & 0,685 & $\begin{array}{c}10,19 \\
7\end{array}$ & 0,000 \\
\hline
\end{tabular}

a. Dependent Variable: Loyalitas pelanggan

Berdasarkan Tabel 4 diperoleh nilai $t$ hitung untuk kualitas pelayanan $=3,199$ dengan nilai $p$-value sebesar 0,002 dan nilai t hitung untuk kepuasan pelanggan $=$ 10,197 dengan nilai $p$-value sebesar 0,000 . Nilai $t$ hitung tersebut lebih besar dari t tabel $=1,984$ dan $p$-value lebih kecil dari $\alpha=0,05$, maka keputusannya $\mathrm{H}_{0}$ ditolak. Jadi, terdapat pengaruh yang signifikan antara kualitas pelayanan dan kepuasan pelanggan terhadap loyalitas pelanggan PT Kantor Pos Pusat Cabang Singaraja.

Besar pengaruh secara tidak langsung kualitas pelayanan terhadap loyalitas pelanggan melalui kepuasan pelanggan ditunjukkan oleh Unstandardized Coefficients Beta pada tabel 3 dan tabel 4 , yaitu $0,109 \times 0,787=$ 0,086 . Besar pengaruh secara langsung dari kualitas pelayanan terhadap loyalitas pelanggan yang ditunjukkan oleh Unstandardized Coefficients Beta pada tabel 4 , yaitu 0,064 dengan nilai signifikan sebesar 0,002 yang lebih kecil dari 0,05. Kesimpulan hasil analisis jalur menunjukkan bahwa kualitas pelayanan dapat berpengaruh langsung terhadap loyalitas pelanggan dan dapat juga berpengaruh tidak langsung, yaitu kualitas pelayanan terhadap kepuasan pelanggan (sebagai variabel intervening). Besarnya pengaruh langsung adalah 0,064, sedangkan besarnya pengaruh tidak langsung harus dihitung dengan mengalikan koefisien tidak langsungnya, yaitu $0,109 \times 0,787=0,086$. Karena koefisien pengaruh tidak langsung lebih besar dari koefisien pengaruh langsung, maka dapat disimpulkan bahwa loyalitas pelanggan lebih dominan dipengaruhi hubungan tidak langsung melalui kepuasan pelanggan. Dengan kata lain, kepuasan pelanggan dalam menunjang loyalitas pelanggan dalam menjelaskan pengaruh kualitas pelayanan relatif tinggi.

\section{Pembahasan}

Pengaruh kualitas pelayanan terhadap loyalitas pelanggan, hasil penelitian menunjukkan bahwa terdapat pengaruh yang siginifikan antara kualitas pelayanan dengan loyalitas pelanggan, yang ditunjukkan dengan nilai $\mathrm{t}$ hitung $=$ 5,745 lebih besar dari $t$ tabel $=1,984$ dan $p$-value sebesar 0,000 lebih kecil dari $\alpha=$ 0,05 . Hal ini menunjukkan bahwa jika kualitas pelayanan semakin tinggi, maka loyalitas pelanggan juga semakin tinggi.

Hasil penelitian ini didukung oleh hasil penelitian terdahulu yang dilakukan oleh Dewi (2012), yang menunjukkan bahwa secara parsial kualitas pelayanan berpengaruh signifikan terhadap loyalitas pelanggan. Penelitian lain yang mendukung hasil penelitian ini dilakukan oleh Wijayanto (2015), yang menyatakan bahwa kualitas pelayanan berpengaruh signifikan terhadap loyalitas. Hasil penelitian ini didukung teori yang dikemukan oleh Lupiyoadi (2006) bahwa jika kualitas diperhatikan, maka loyalitas pelanggan akan lebih mudah diperoleh. Kualitas pelayanan dapat memberikan suatu dorongan kepada pelanggan untuk menjalin ikatan hubungan yang kuat dengan perusahaan. Menurut Kotler (2003), dalam jangka panjang ikatan hubungan yang kuat memungkinkan perusahaan untuk memahami dengan 
seksama harapan pelanggan serta kebutuhan mereka. Dengan demikian, perusahaan dapat mencapai tujuan yaitu loyalitas pelanggan sepenuhnya melalui peningkatan kualitas pelayanan yang sesuai dengan harapan pelanggan sehingga memiliki daya saing di pasar.

Pengaruh kepuasan pelanggan terhadap loyalitas pelanggan, hasil penelitian menunjukkan bahwa terdapat pengaruh yang siginifikan antara kepuasan pelanggan dengan loyalitas pelanggan, yang ditunjukkan dengan nilai t hitung $=12,146$ lebih besar dari $t_{\text {tabel }}=$ 1,984 dan $p$-value sebesar 0,000 lebih kecil dari $\alpha=0,05$. Hal ini menunjukkan bahwa jika kepuasan pelanggan semakin tinggi, maka loyalitas pelanggan juga semakin tinggi.

Hasil penelitian ini didukung oleh hasil penelitian terdahulu yang dilakukan oleh Normasari (2013), yang menunjukkan bahwa kepuasan berpengaruh signifikan terhadap loyalitas pelanggan. Penelitian lain yang mendukung hasil penelitian ini dilakukan oleh Hairany (2014), yang menyatakan bahwa kepuasan berpengaruh signifikan terhadap loyalitas pelanggan. Hasil penelitian ini didukung teori yang dikemukan oleh Tjiptono \& Chandra (2012) bahwa kepuasan pelanggan memberikan manfaat utama bagi perusahaan, yaitu berupa terciptanya loyalitas pelanggan. Senada dengan itu, Umar (2005) menjelaskan bahwa seorang pelanggan jika telah merasa puas dengan nilai yang diberikan oleh produk atau jasa, sangat besar kemungkinannya menjadi pelanggan yang loyal kepada perusahaan dalam waktu yang lama. Hal tersebut juga ditegaskan oleh Kotler \& Keller (2009) bahwa pelanggan yang sangat puas biasanya akan tetap loyal untuk waktu yang lebih lama, membeli lagi ketika perusahaan memperkenalkan produk baru dan memperbaharui produk yang lama, membicarakan hal-hal baik tentang perusahaan dan produknya kepada orang lain dan tidak terlalu sensitif terhadap harga.

Pengaruh kualitas pelayanan terhadap kepuasan pelanggan, hasil penelitian menunjukkan bahwa terdapat pengaruh yang siginifikan antara kualitas pelayanan dengan kepuasan pelanggan, yang ditunjukkan dengan nilai $t$ hitung $=$ 4,567 lebih besar dari $t$ tabel $=1,984$ dan $p$-value sebesar 0,000 lebih kecil dari $\alpha=$ 0,05 . Hal ini menunjukkan bahwa jika kualitas pelayanan semakin tinggi, maka kepuasan pelanggan juga semakin tinggi.

Hasil penelitian ini didukung oleh hasil penelitian terdahulu yang dilakukan oleh Normasari (2013), yang menunjukkan bahwa kualitas pelayanan memiliki pengaruh signifikan terhadap kepuasan pelanggan. Penelitian lain yang mendukung hasil penelitian ini dilakukan oleh Panjaitan (2016), yang menyatakan bahwa kualitas layanan memiliki pengaruh signifikan terhadap kepuasan pelanggan. Hasil penelitian ini didukung teori yang dikemukan oleh Lupiyoadi \& Hamdani (2009) bahwa kualitas pelayanan karyawan terhadap pelanggan berpengaruh terhadap kepuasan pelanggan, dimana pelayanan yang buruk berakibat lebih besar terhadap rendahnya kepuasan pelanggan daripada pelayanan yang dikategorikan baik. Tjiptono (2004) juga menjelaskan bahwa perusahaan harus memulai memikirkan pentingnya pelayanan secara lebih matang melalui kualitas pelayanan, karena kini semakin disadari bahwa kepuasan pelanggan merupakan aspek vital dalam rangka bertahan dalam bisnis dan memenangkan persaingan. Agar dapat bersaing, bertahan, dan berkembang, maka perusahaan dituntut untuk mampu memberikan pelayanan berkualitas yang dapat memenuhi kebutuhan dan keinginan pelanggan sehingga kepuasan pelanggan semakin tinggi.

Pengaruh tidak langsung antara kualitas pelayanan dengan loyalitas pelanggan melalui kepuasan pelanggan, hasil penelitian menunjukkan bahwa kualitas pelayanan mempunyai pengaruh signifikan secara tidak langsung terhadap loyalitas pelanggan melalui kepuasan pelanggan, yang ditunjukkan dengan nilai t hitung untuk kualitas pelayanan $=3,199$ dengan nilai $p$-value sebesar 0,002 dan nilai t hitung untuk kepuasan pelanggan = 10,197 dengan nilai $p$-value sebesar 0,000 . Nilai $t$ hitung tersebut lebih besar dari t tabel $=1,984$ dan $p$-value lebih kecil 
dari $\alpha=0,05$. Selain itu, koefisien pengaruh tidak langsung lebih besar dari koefisien pengaruh langsung, maka dapat disimpulkan bahwa loyalitas pelanggan lebih dominan dipengaruhi hubungan tidak langsung melalui kepuasan pelanggan.

Hasil penelitian ini didukung oleh hasil penelitian terdahulu yang dilakukan oleh Iskandar (2015), yang menunjukkan bahwa kualitas pelayanan mempunyai pengaruh signifikan secara tidak langsung terhadap loyalitas pelanggan melalui kepuasan pelanggan. Hasil penelitian ini didukung teori yang dikemukan oleh Kartajaya (2006) bahwa pelanggan yang terpuaskan cenderung punya potensi tinggi untuk menjadi loyal terhadap suatu produk atau jasa dimana kepuasan seperti itu mustahil ada tanpa diawali oleh pelayanan yang prima. Pelanggan yang memutuskan untuk loyal terhadap suatu produk atau jasa seringkali disebabkan karena mereka merasakan pelayanan yang diberikan oleh perusahaan tidak hanya sesuai dengan kebutuhan, tetapi juga memuaskan dan menyenangkan.

\section{SIMPULAN DAN SARAN}

Kesimpulan hasil analisis jalur menunjukkan bahwa kualitas pelayanan dapat berpengaruh langsung terhadap loyalitas pelanggan dan dapat juga berpengaruh tidak langsung, yaitu kualitas pelayanan terhadap kepuasan pelanggan (sebagai variabel intervening). Besarnya pengaruh langsung adalah 0,064, sedangkan besarnya pengaruh tidak langsung harus dihitung dengan mengalikan koefisien tidak langsungnya, yaitu $0,109 \times 0,787=0,086$. Karena koefisien pengaruh tidak langsung lebih besar dari koefisien pengaruh langsung, maka dapat disimpulkan bahwa loyalitas pelanggan lebih dominan dipengaruhi hubungan tidak langsung melalui kepuasan pelanggan. Dengan kata lain, kepuasan pelanggan dalam menunjang loyalitas pelanggan dalam menjelaskan pengaruh kualitas pelayanan relatif tinggi. Kualitas pelayanan jasa dapat dijadikan tolak ukur tingkat keberhasilan suatu usaha, kenyamanan pelanggan PT Kantor Pos Pusat Cabang Singaraja harus ditingkatkan dalam melayani pelanggan dan untuk karyawan harus segera meningkatkan disiplin waktu agar tidak terlambat dalam memberikan pelayanan kepada pelanggan. Kualitas pelayanan dan kepuasan pelanggan merupakan faktor yang mempengaruhi keberhasilan PT Kantor Pos Pusat Cabang Singaraja membuat pelanggan tetap

\section{DAFTAR PUST AKA}

Christopher, Lovelock, Jochen, Wirtz, Jacky Mussry. 2010. Pemasaran Jasa, Edisi-7. Jakarta: Erlangga

Dewi, L.R. 2012. Pengaruh Kualitas Pelayanan Terhadap Loyalitas Pelanggan Pengguna Jasa Warung Internet di Kota Singaraja Tahun 2012. Skripsi tidak diterbitkan, Universitas Pendidikan Ganesha

Hairany, Eni. 2014. Pengaruh Kepuasan dan Kepercayaan Terhadap Loyalitas Pelanggan Lembaga Pengembangan dan Sertifikasi Batu Mulia (LPSB) di Martapura Kabupaten Banjar. Jurnal Wawasan Manajemen. 2 (3), 251 260

Irawan, H. 2002. 10 Prinsip Kepuasan Pelanggan. Edidi-1, Jakarta: Elex Media Komputindo

Iskandar, Priasmoro 2015. Pengaruh Kualitas Pelayanan Terhadap Loyalitas Pelanggan Melalui Kepuasan Sebagai Variabel Intervening pada Pengguna Jasa Transportasi PT. Tara Megah Muliatama (Taksi Gemah Ripah) di Kota Bandung. e-Proceeding of Management. 2 (3), 3953-3960

Kartajaya, Hermawan. 2006. Hermawan Kertajaya on Marketing Mix. Bandung: Mizan Pustaka

Kotler, Philip. 2003. Manajemen Pemasara, Jakarta: PT. Prebalindo

Koter, Philip \& Kaller, Kevin Lane. 2009. Manajemen Pemasaran. Jakarta: Erlangga 
Lupiyoadi, R. 2006. Manajemen Pemasaran Jasa. Jakarta: Penerbit Salemba Empat

Lupiyoadi, R. \& Hamdani, A. 2009. Manajemen Pemasaran Jasa. Jakarta: Penerbit Salemba Empat

Normasari, Selvy. 2013. Pengaru Kualitas Pelayanan Terhadap Kepuasan Pelanggan, Citra Perusahaan dan Loyalitas Pelanggan Survei pada Tamu Pelanggan yang Menginap di Hotel Pelangi Malang. Jurnal Administrasi Bisnis (JAB), 6 (2), 19

Nugroho, J. 2003. Perilaku Konsumen. Edisi Revisi, Tambra Raya Rawamangun, Jakarta: Prenamedia

Panjaitan, Januar Efendi. 2016. Pengaruh Kualitas Pelayanan Terhadap Kepuasan Pelanggan pada JNE Cabang Bandung. Jurnal Manajemen, 11 (2), 265-289

Sentot Iman, W 2010. Manajemen Pemasaran Bank. Edisi-1, Yogyakarta: Graha IImu

Solimun, 2002. Multivariate Analysis Sem, Lisrel dan Amos, Aplikasi Manajemen, Ekonomi Pembangunan, Psikologi, Sosial, Kedokteran dan Agrokompleks. Malang: UM

Sopiah, Etta Mamang Sangadji 2013. Perilaku Konsumen. Edisi-1, Yogyakarta: C.V Andi Offset

Tjiptono, Fandy. 2004. Strategi Pemasaran: Yogyakarta. Penerbit Andi

Tjiptono, Fandy \& Chandra, Gregorius. 2012. Pemasaran Strategik. Yogyakarta: Penerbit Andi
Umar, Husein. 2005. Metode Penelitian. Jakarta: Salemba Empat

Vanessa, G. 2007. CRM dan MPR Hotel. (Customer Relationship Management and Marketing Public Relations). Bandung: Alfabeta

Wijayanto, Kusuma. 2015. Pengaruh Kualitas Pelayanan Terhadap Kepuasan dan Loyalitas Nasabah Bank. Jurnal Ekonomi Manajemen Sumber Daya, 17 (1), 38-45

Zulkarnain, 2012. Ilmu menjual, Edisi-2, Yogyakarta: Graha IImu 